\title{
Beliren Yetişkinlikte İntihar Olasılığı: Stresle Başetme, Öfke ve Cinsiyet Açısından Bir İnceleme
}

\section{Suicide Probability in Emerging Adulthood: An Analysis in terms of Coping with Stress, Anger and Gender}

\author{
Zeynep KARATAŞ*, Öner ÇELIKKKALELI***
}

\begin{abstract}
Öz: Çalışmada beliren yetişkinler arasında görülen intihar olasılığının stresle baş etme ve öfke ile ilişkili olup olmadığı incelenerek, intihar olasıllığının stresle baş etme becerileri ve öfke tarafından ne derece yordanıp yordanmadığının belirlenmesi ve intihar olasılığının cinsiyet açısından farklılaşıp farklılaşmadığının incelenmesi amaçlanmıştır. Çalışma, ilişkisel tarama modeline dayalı olarak gerçekleştirilmiştir. Çalışma grubunu batı illerinde iki farklı üniversitenin Eğitim Fakültelerinde öğrenim gören beliren yetişkinlerden, gönüllülük esasına dayalı olarak belirlenen 149 (\%63.4) kadın ve 86 (\%36.6) erkek toplam 235 üniversite öğrencisi oluşturmaktadır. Araştırmada intihar olasılığını belirlemek için Cull ve Gill tarafından geliştirilen, Atlı, Eskin ve Dereboy tarafından Türkçeye uyarlanan İntihar Olasılığı Ölçeği, stresle başetme yollarını belirlemek için Amirkhan tarafindan geliştirilen ve Aysan tarafindan Türkçeye uyarlanan Başa Çıkma Stratejileri Ölçeği, öfkeyi belirlemek için Spielberger tarafından geliştirilen ve Özer tarafından Türkçeye uyarlanan Öfke İfade Tarzı Ölçeği kullanılmıştır. Verilerin analizinde, Pearson Momentler Çarpım Korelasyon Katsayısı, Çoklu Regresyon Analizi ve Bağımsız Gruplar t-Testi kullanılmıştır. Araştırmada, beliren yetişkinlik döneminde olan üniversite öğrencilerinde intihar olasılığının stresle başetme ve öfkeleri ile ilişkili olduğu, intihar olasıllığının stresle başetme alt ölçeklerinden problem çözme, kaçınma ve öfke alt ölçeklerinden öfke içe ve öfke dışa boyutları tarafindan anlamlı olarak yordandığı bulgusuna ulaşılmış̧ır. Ayrıca intihar olasıllığının stresle başetme alt boyutu olan sosyal destek arama ve öfke alt boyutu olan öfke kontrolü tarafindan anlamlı olarak yordanmadığı ve intihar olasılığı puanlarının cinsiyet açısından anlamlı olarak farklılaşmadığ saptanmış̧ır.

Anahtar Kelimeler: Beliren yetişkinlik, intihar olasıllı̆̆, stresle başetme becerileri, öfke
\end{abstract}

\begin{abstract}
In the current study, it is aimed to determine whether the suicide likelihood seen among emerging adults is related to coping with stress and anger and the extent to which the suicide likelihood is predicted by stress-coping skills and anger and to investigate whether the suicide likelihood varies depending on gender. The study was conducted in line with the relational survey model. The study group of the current research is comprised of a total of 235 university students (149 (66.3\%) are females and 86 $(36.6 \%)$ are males) attending the education faculties of two different universities located in the western part of Turkey. In order to determine the suicide likelihood, the Suicide Likelihood Scale developed by Cull and Gill and adapted to Turkish by Atli, Eskin and Dereboy; to determine the ways of coping with stress, the Coping Strategies Scale developed by Amirkhan and adapted to Turkish by Aysan and to determine the level of Anger, the Anger Expression Style Scale developed by Spielberger and adapted to Turkish by Özer were used. In the analysis of the collected data, Pearson product-moment correlation coefficient, multiple regression analysis and independent samples t-test were used. In the current study, it was found that during the emerging adulthood period, university students' suicide likelihood is associated with stress coping and anger and that the suicide likelihood is predicted by problem solving and avoidance sub-scales of stress coping and anger inwards and anger outwards dimensions of anger. Moreover, it was found that the suicide likelihood is not significantly predicted by seeking for social support, one of the sub-dimensions of stress coping and anger control, one of the sub-dimensions of anger and the suicide likelihood scores do not vary significantly by gender.

Keywords: Emerging adulthood, suicide probability, stress coping skills, anger
\end{abstract}

\footnotetext{
*Doç. Dr., Mehmet Akif Ersoy Üniversitesi, Eğitim Fakültesi, Burdur, Türkiye, ORCİD NO: 0000-0002-4532-6827, e-posta: zeynepkaratas1972@ hotmail.com,

**Dr. Öğretim Üyesi, Muğla Sitkı Koçman Üniversitesi, Eğitim Fakültesi, Muğla, Türkiye, ORCİD NO: 0000-00030210-3647, e-posta: celikkaleli@gmail.com,
} 


\section{Giriş}

Dünyada ve Türkiye'de intihar gerek gençler gerekse yetişkinler arasında gözlenen son derece ciddi bir problemdir. İntihar girişiminin ölümle sonuçlansın ya da sonuçlanmasın hem sağlık problemi hem de psikolojik etkileri açısından kalıcı izler bırakması beklenen bir durumdur. Dünya Sağlık Örgütü (WHO) (2014) yayınladığı intiharı önleme raporunda intiharın önlenebilir bir durum olduğunu fakat her kırk saniyede bir kişinin dünyanın herhangi bir yerinde intihar sonucunda öldügünü, 15-29 yaş aralığındaki gençler arasında intiharın ölüm sebebi olarak ikinci sırada yer aldığını ve yaygın bir sağlık sorunu olduğunu belirtmiş̧ir. Ayrıca intiharın gelişmiş ülkelerde ciddi bir sorun olmadığı, daha çok kaynakların ve hizmetlerin kıt olduğu, erken tanılama, tedavi ve destek birimlerinin yetersiz olduğu düşük ve orta gelirli ülkelerde daha çok gerçekleştiğini belirtmektedir. Bu raporda 2012 yılında 804.000 intihar vakası yaşandığı her y1l neredeyse bir milyona yakın kişinin intihar sonucu öldügü açıklanırken, intihar sonucu ölümün genel nüfusa oranının her yüz bin kişide 11.4 olduğu cinsiyet açısından ise her yüz bin kişide erkeklerde 15, kadınlarda ise 8 oranında gerçekleştiği görülmektedir. Manchester Üniversitesi ve HQIP işbirliği ile yapılan çalışmada (2017), dünyada intiharın 15-29 yaş aralığında tüm ölümlerin \%8'ini oluşturduğu ve ikinci önde gelen ölüm sebebi olduğu ayrıca erkeklerde görülen intihar oranının kadınlarda görülen intihar oranına göre daha yüksek olduğu ortaya koyulmuştur. Yaş aralığ 20-25 olan bireylerde intihar öncülleri olarak \%13 zihinsel hastalıklar, $\% 17$ fiziksel hastalıklar, \%17 duygusal, fiziksel ve cinsel istismar, \%10 madde kullanımı, \%17 intiharla ilişkili internet kullanımı, \%57 alkol kötüye kullanımı, \%60 yasadışı madde kullanımı, $\% 57$ kendine daha önce zarar vermiş olma, \%67 her an intihar düşüncesi ve \%60 herhangi bir akı1 hastalığ tanısı olmasını rapor etmişlerdir.

Türkiye'de TÜİK (2016) verilerine göre ölümle sonuçlanan intihar sayısı 2014 yılında 3 bin 169 iken 2015 yılında \%1,3 artarak 3 bin 211 kişi olmuştur. İntihar edenlerin \%72,7'sini erkekler, \%27,3'ünü ise kadınlar oluşmaktadır. İntihar eden kişiler yaş grubuna göre incelendiğinde, 2015 yılında intihar edenlerin \%34,3'ünü 15-29 yaş grubundakiler oluşturmaktadır. İntihar eden kişiler cinsiyete göre incelendiğinde, intihar eden kadınlarda en yüksek oran \%18 ile 15-19 yaş grubunda bulunurken, erkeklerde ise bu oranın en yüksek \%12,8 ile 20-24 yaş grubunda olduğu görülmektedir. İntihar eden erkeklerin \%33,3'ünün, kadınların ise \%46'sının 30 yaşından küçük olduğu görülmektedir.

Oranlara bakıldığında intiharın beliren yetişkinlerde ne kadar önemli bir sorun olduğu ve üzerinde durulması gerektiği oldukça açıktır. Beliren yetişkinlik kavramı ilk kez ABD’li gelişim psikoloğu Jeffrey Jensen Arnett tarafından ortaya atılmış ve yeni bir gelişimsel kavram olarak karşımıza çıkmış, ergenlik ile yetişkinlik arasındaki 18-29 yaş aralığındaki dönemi kapsayan belirgin bir gelişimsel dönem olarak tanımlanmıştır (Arnett, 2000; Atak ve Çok, 2010; Doğan ve Cebioğlu, 2011). Bu gelişimsel dönem bireyler için çeşitli yeni firsatlarla karşılaşıldığı bir dönem olmasına karşın belirli zorlukların yaşandığ ve bu zorluklarla başedilmesi gereken bir dönemdir. Hangi yaşta ya da dönemde olursa olsun intiharı, girişim olmadan önlemek ve destek hizmetleri vermek oldukça önem arz etmektedir. Bu yüzden intihar olasılığı ile ilişkili bir takım etmenleri de göz ardı etmemek gereklidir. İntiharla ilişkili olabilecek etmenlerin araştıııldığı bir araştırmada (Apaydın, Özdemir ve Zaroğlu Ünal, 2016), kaygı ve korku, takıntı ve saplantı, panik atak ve fobi, depresyon ve stres, umutsuzluk, çeşitli kişisel özellikler ele alınmış intiharın bu değişkenlerle ilişkili olduğu vurgulanmıştır. İntihar riskini arttıran psikososyal etmenlerin incelendiği bir başka çalışmada ise (Ekici, Savaş ve Çıtak, 2001), sosyal güvence yokluğu, göç tutuklanma, işten çıkarılma, boşanma, tecavüze uğrama gibi stres faktörlerinin intihar riskini arttırdığı sonucuna ulaşılmıştır. Takahashi (2001), intiharların \%34.9'unun sebebinin en çok fiziksel hastalıklar olduğunu ayrıca intiharın depresyonla ilişkisi olduğunu vurgularken, Amerikan İntihar Derneği (2014), depresyon ve intihar riski ilişkisini araştırmış ve tedavi edilmemiş depresyonu olan hastalarda yaşam boyu intihar riskinin \%2.2 ile \% 15 aralığında olduğunu ortaya koymuştur. Ayrıca bütün intiharların en az \%50'sinde depresyon gözlendiğini belirtirken, depresyonda olan bireylerin genel nüfustaki sağlıklı bireylere göre daha yüksek intihar riskinde olduğunu ortaya koymuşlardır. Depresyonun yaşam kalitesini bozduğu ve stresle başetmeyi olumsuz yönde etkileyebildiği 
düşünülürse bu oranın intihar olasılığında ne kadar önemli olduğu bir gerçektir. Farklı çalışmalarda ise (Arsel ve Durak Batıgün, 2011; Aslan ve Durak Batıgün, 2017; Dilli, Dallar ve Çakır, 2010; Durak Batıün, 2004, 2005, 2008; Hisli Şahin ve Durak Batıgün, 2009; Hisli Şahin, Onur ve Basım, 2008), intihar ile ilişkili olarak cinsiyet, cinsiyet rolleri, iletişim becerileri, yalnızlık, umutsuzluk öfke, saldırganlık, dürtüsel davranışlar, problem çözme becerileri, sosyal destek, ebeveyn kabul/reddi, yaşam amaçları ve yaşamı sürdürme nedenleri ele alınmış ve bu değişkenlerin intiharla anlamlı olarak ilişkili olduğu vurgulanmıştır. Emir Öksüz ve Bilge (2014), üniversite öğrencilerinde intihar olasılığını araştırmış ve intihar olasılığının olumsuz benlik ve tükenme, hayata bağl1lıktan kopma ve öfke düzeyleri, sosyal problem çözme ve kişilerarası öfke ile ilişkili olduğunu belirtmişlerdir. Franklin ve diğerleri (2017), intiharla ilişkili değişkenlere yaptığı meta-analitik çalışmalarında son 50 yılda yapılan 365 çalışmanın büyük çoğunluğunun çoklu risk faktörünü araştırmadığı bu yüzden de intiharla ilgili çok fazla bilgi vermedikleri aslında daha çoklu risk faktörünün ele alındığı çalışmalara ihtiyaç duyulduğunu belirtmişlerdir. Ayrıca koruyucu faktörlerin ele alındığı çalıșmaların yetersiz olduğu koruyucu faktörler olarak genelde demografik değişkenlerin ele alındığı onların da etki büyüklüğünün çok düşük olduğunu belirtmişlerdir. DSÖ (WHO, 2014), çeşitli felaketler, savaşlar gibi global risklerin yanı sıra bireysel risklerden olan alkol kullanım, zihinsel engeller, önceki intihar girişimleri, maddi kayıplar, finansal bozulmalar, kronik ağrılar ve ailede intihar öyküsünün olmasının intihar riski ile ilişkili olduğunu belirtmiştir.

İntihar davranışına ilişkin biyokimyasal çalışmalar incelendiğinde hormonlar üzerinde özellikle kortizol'ün etkisi üzerinde durdukları görülmüştür. Biyolojik intihar araştırmalarının gözden geçirildiği çalışmalarda depresif hastalarda kortizol düzeyinin yüksek bulunduğunu ancak bunun intihar davranışı ile ilişkisini destekleyecek kanıtların yetersiz olduğu görülmekle birlikte, depresif hastalardaki kortizol düzeyinin yüksek olmasını stresle açıklayan ve stresin insanlardaki kortizol düzeyini arttırdığını belirten çalışmalar da olduğu görülmektedir (Gonong, 2002; Vander, Sherman ve Luciano, 2001). Bu nedenle kortizol düzeyi yüksek olan ve intihar davranışı sergileyen depresif hastaların bu davranışlarının doğrudan kortizol düzeyine mi yoksa kortizol düzeyinin yükselmesine neden olan strese mi bağlanması gerektiği kafalarda soru işareti bırakmaktadır (Atl1, 2007). Bu yüzden açıklanan bu ilişkiler intihar olaylarında özellikle stresli durumların ve bu durumlarla başetmenin öneminin ne derece etkili olduğunu ortaya koymaktadır. Çalışmalarda ortaya konulduğu gibi intiharla ilişkili olan etmenlerden birisi olan bireylerin stresli durumlarla karşılaştıklarında, stresleri arttıkça o durumla baş etmeleri de zorlaşmaktadır. İntihar ve stresin birbirleri ile ilişkili olduğunu ortaya koyan çalışmalarda (Apaydın, Özdemir ve Zaroğlu Ünal, 2016; Buzlu, 1999; Şener, 1994), intiharın stres yaratan yaşam koşullarına tepki veren kişilerden, ağır ruhsal bozukluğu olan hastalara kadar geniş bir yelpazedeki nüfusu kapsadığı ve bu durumun çok sayıdaki nedenin birleşimi ile oluşan çok karmaşık yapıda olduğu belirtilmiştir.

Stresin yapısı incelendiğinde stres yaratıcı etmenler arasında bireysel ve sosyal stres kaynaklarını görmek mümkündür. Bireysel stres kaynaklarında gelecekle ilgili beklentiler, endişeler, çeşitli baskılar, kişisel bağımsızlığı kazanmada karşılaşılan güçlükler, kimlik gelişimi bulunurken, sosyal stres kaynaklarında eğitim, iş kaygısı, toplumsal desteklerin azalması, aile desteğinin azalması, toplumsal ve kültürel değerlerle yaşanan çatışmalar sayılabilir. Stresin yapısından da anlaşıldığı gibi bireyin bu etmenlerden kaçması imkansızdır. Bu yüzden bu etmenlere karş1 uygun tepkiler geliştirmek stresle baş etmeyi kolaylaştıracak ve işin daha da içinden çıkılmaz hale dönüşmesini engelleyecektir. Özellikle gençlere uygun stresle başetme tepkilerinin öğretilmesi yaşama kolay uyum sağlamaları ve intihar olasıllğını azaltmada son derece önemlidir (Buzlu, 1999).

İntihar olasıllı̆̆ ile ilişkili bir başka önemli etmen ise öfkedir. Öfke kişinin belirli bir saldırı, eleştiri ya da engel durumunda yaşadığı içsel ve evrensel bir duygudur (Hankins ve Hankins, 1988). Öfkenin açığa çıkması normal bir durumken, asıl önemli olan evrensel bir duygu olan öfkenin nasıl ortaya konulduğu ve öfke ile nasıl sağlıklı baş edildiğidir. Yapılan çalışmalarda da görülmüştür ki (Durak Batıgün, 2004; Hisli Şahin ve Durak Batıgün, 2009) öfke 
ile sağlıklı baş edilemediğinde bireyi intihar davranışlarına sürükleyici bir neden olması kaçınılmazdır.

Alanyazında intihar ve intihar olasılığının ele alındığı çok sayıda çalışma olduğu görülmektedir (American Association of Suicidology [Amerikan İntihar Derneği], 2014; Apaydın, Özdemir ve Zaroğlu Ünal, 2016; Arsel ve Durak Batıgün, 2011; Aslan ve Durak Batıgün, 2017; Atl1, 2007; Atl1, Eskin ve Dereboy, 2009; Buzlu, 1999; DSÖ (WHO), 2014; Dilli, Dallar ve Çakır, 2010; Durak Batıgün, 2004, 2005, 2008; Eisenberg, Gollust, Golberstein, Hefner, 2007; Ekici, Savaş ve Çıtak, 2001; Emir Öksüz ve Bilge, 2014; Franklin ve diğerleri 2017; Görgülü ve Tutarel Kışlak, 2014; Hisli Şahin ve Durak Batıgün, 2009; Hisli Şahin, Onur ve Basım, 2008; Karbeyaz, Toygar ve Çelikel, 2016; Kessler, Borges ve Walters, 1999; Kjoller ve Helweg Larsen, 2000; Klonsky, May ve Saffer, 2016; Korb ve Plattner, 2014; Mackenzie ve diğerleri, 2011; Manchester Üniversitesi ve HQIP, 2017; McAuliffe, Corcoran, Keeley ve Perry, 2003; Nock ve diğerleri, 2008; Şener, 1994, Takahashi, 2001; Westefeld, Whitchard ve Range, 1990). Bu çalışmalar incelendiğinde intihar olasılığının stresle başetme ve öfke ile birlikte ele alındığ1 çalışmaya rastlanmamıştır. Ayrıca bu çalışmalar daha çok klinik örneklem üzerinde yapılmışken çok az kısmı beliren yetişkinlik döneminde olan üniversite öğrencileri örneklemi üzerinde yapılmıştır (Aslan ve Durak Batıün, 2017; Eisenberg, Gollust, Golberstein, Hefner, 2007; Emir Öksüz ve Bilge, 2014; Hisli Şahin ve Durak Batıgün, 2009; Karbeyaz, Toygar ve Çelikel, 2016; Korb ve Plattner, 2014; Mackenzie ve diğerleri, 2011; McAuliffe, Corcoran, Keeley ve Perry, 2003; Westefeld, Whitchard ve Range, 1990).

Yukarıda ele alınan tüm bu açıklamalardan da anlaşılacağı gibi intihar olasılığının yaygın olarak gözlenebileceği beliren yetişkinler arasında intihar olasılığının ele alınması son derece önem arz etmektedir. Ayrıca bu çalışmada intihar olasılığı ile stres, stresle baş etme ve öfkenin ele alınacak olması da beliren yetişkinlik döneminde olan gençlerde stresli yaşam koşullarının intihar olasılığında ne denli önemli olup olmadığını belirlemeye yönelik durum saptaması için önemli görünmektedir. Bu çalışma ile intihar olasılığına etki eden etmenlerden stres ve öfkenin ne kadar etkili olduğu saptandığında bu değişkenlerin intihar olasılığındaki önem durumlarına göre birlikte ele alındığı önleyici çalışmalara öncülük etmesi amaçlanmaktadır. Ayrıca bu çalışma ile beliren yetişkinlik döneminde bulunan genç kadınlar ve erkekler arasında intihar olasılı̆̆ının yaygınlığı saptanarak, kadın ya da erkeklerle önleyici çalışmalar planlanabilecek ve bu çalışma alan yazındaki intihar olasılığı ile ilgili bilgi birikimine katkı sağlayacaktır. Bütün bunlardan hareketle bu çalışmanın amacı beliren yetişkinler arasında görülen intihar olasılığının stresle baş etme ve öfke ile ilişkili olup olmadığının incelenmesi ve intihar olasılığının stresle baş etme becerileri ve öfke tarafindan ne derece yordanıp yordanmadığının belirlenmesidir.

\section{Yöntem}

Beliren yetişkinlik döneminde olan üniversite öğrencilerinin intihar olasıllı̆ıının stresle baş etme ve öfke ile ilişkili olup olmadığının, intihar olasılığının stresle başetme becerileri ve öfke tarafından yordanıp yordanmadığının belirlenmesine yönelik yapılan bu çalışma, ilişkisel tarama modeline dayalı olarak gerçekleştirilmiş̧ir.

\section{Çalışma grubu}

Araştırmanın çalışma evrenini Mehmet Akif Ersoy ve Muğla Sıtkı Koçman Üniversitesi Eğitim Fakültesi öğrencileri oluşturmaktadır. Çalışma grubunu, 2016-2017 eğitim öğretim y1lında Burdur Mehmet Akif Ersoy ve Muğla Sitkı Koçman Üniversitesi Eğitim Fakültelerinde öğrenim gören beliren yetişkinlerden, gönüllülük esasına dayalı olarak belirlenen 149 (\%63.4) kadın ve 86 (\%36.6) erkek, 69'u Fen, 108'i Türkçe Matematik, 58'i Sosyal alanlarında öğrenim gören, 107'si birinci sınıf, 32'si ikinci sınıf, 64'ü üçüncü sınıf, 32'si dördüncü sınıf, yaş ortalamaları 20.80 olan toplam 235 üniversite öğrencisi oluşturmaktadır. 


\section{Veri toplama araçları}

Araştırmada intihar olasılığını belirlemek için Cull ve Gill tarafından geliştirilen, Atlı, Eskin ve Dereboy (2009) tarafından Türkçeye uyarlanan İntihar Olasılığı Ölçeği, stresle başetme yollarını belirlemek için Amirkhan tarafından geliştirilen ve Aysan (2003) tarafından Türkçeye uyarlanan Başa Çıkma Stratejileri Ölçeği, öfkeyi belirlemek için Spielberger tarafından geliştirilen ve Özer (1994) tarafindan Türkçeye uyarlanan Öfke İfade Tarzı Ölçeği kullanılmıştır. Ayrıca demografik bilgilerin toplanması için araştırmacılar tarafından hazırlanmış olan bilgi formu kullanılmıştır.

Intihar Olasılı̆̆g Ölçeği: Cull ve Gill tarafından geliştirilen, Atlı, Eskin ve Dereboy (2009) tarafından Türkçeye uyarlanan İntihar Olasılı̆̆ı Ölçeği 36 maddelik bir ölçektir. Ölçek umutsuzluk, intihar düşüncesi, olumsuz kendilik değerlendirmesi ve düşmanlık olmak üzere dört alt ölçekten oluşmakta ve ölçekten toplam puan alınmaktadır. Türkçeye uyarlama çalışmasında ölçeğin yapı geçerliği için Doğrulayıcı Faktör Analizi yapılmış ve dört faktörlü yapının doğrulandığı görülmüştür. Güvenirlik analizinde Cronbach alpha değerleri sırasıyla, .78, $.94, .79, .70$ ve toplam ölçek için ise .89 bulunmuştur. Ölçeğin kesme noktas 110 olarak belirlenmiş̧ir. Bu çalışmanın verileri ile hesaplanan Cronbach alpha iç tutarlık katsayısı toplam ölçek maddeleri için .62'dir.

Başaçıkma Stratejileri Ölçeği: Amirkhan tarafından geliştirilen ve Aysan (2003) tarafından Türkçeye uyarlanan Başa Çıkma Stratejileri Ölçeği 33 madde, problem çözme, sosyal destek arama, kaçınma olmak üzere üç alt ölçekten oluşan bir ölçektir. Alt ölçeklerden alınabilecek en düşük puan 11 , en yüksek puan $33^{\prime}$ tür. Yüksek puanlar ölçülen başa çıkma stratejisinin yüksekliğini göstermektedir. Ölçeğin alt ölçekler için bulunan Cronbach-alfa güvenirlik katsayısı .81-.83 arasında değişmektedir. Benzer ölçekler geçerlik çalışmalarında problem çözme alt ölçeğinin dış kontrole inanç ile negatif yönde; sosyal destek aramanın yüksek depresyon puanı ile negatif yönde, kaçınma alt ölçeğinin depresyon düzeyi ile pozitif yönde ilişkili olduğu belirlenmiştir. Bu çalışmanın verileri ile hesaplanan Cronbach alpha iç tutarlık katsayıs1, problem çözme için .84, sosyal destek arama için .81, kaçınma boyutu için ise .73 olarak bulunmuştur.

Öfke Iffade Tarzı Ölçeği: Spielberger tarafından geliştirilen ve Özer (1994) tarafından Türkçeye uyarlanan Öfke Tarzı Ölçeğinin üç alt ölçeği bulunmaktadır. Öfke Kontrol ölçeğindeki yüksek puanlar öfkenin kontrol edilebildiğini; Öfke Dışa ölçeğindeki yüksek puanlar, öfkenin kolayca ifade edilebildiğini ve Öfke İçte ölçeğindeki yüksek puanlar ise öfkenin bastırılmış olduğunu göstermektedir. Türkçeye uyarlama çalışmasında yapı geçerliği için veriler Varimax tekniği ile 3'lü faktör analizine tabii tutularak, ölçeklerin faktör yapıları incelenmiştir. Öfke Tarz ölçeğinin faktör yapısının orijinal ölçeğin faktör yapısını yansıttığı gözlenmiştir. 1. Faktör 8 maddelik "Öfke kontrol"; 2. faktör 8 maddelik "Dışa vurulmuş öfke" ve 3. faktör 8 maddelik "Bastırılmış öfke" boyutunda oluşmuştur. Yapı geçerliğini sınayan bir diğer çalışmada araştırmaya katılan denek grupları arasındaki farklılık için tek yönlü varyans analizi yapılmıştır. Tüm alt ölçeklerde görülen farklılıklar $\mathrm{p}<.001$ düzeyinde anlamlı bulunmuştur. Ölçüt bağıntılı geçerlik: Sürekli Öfke ve Öfke İfade Tarzı ölçeklerinin, Sürekli Kaygı, Depresif Sıfatlar Listesi ile ve Öfke Envanteri ile korelasyonlarına bakılmış, elde edilen korelasyonlar .01 ve .001 düzeyinde anlamlı bulunmuştur. Güvenirlik analizinde Cronbach Alfa değerleri; "Kontrol altına alınmış öfke" boyutu için .84; "dışa vurulmuş öfke" boyutu için .78 ve "içe yönelik öfke" boyutu için ise .62 olarak bulunmuştur. Bu çalışmanın verileri ile hesaplanan Cronbach alpha iç tutarlık katsayısı öfke kontrol için .83, öfke dışa için .67, öfke içe için ise .64 olarak bulunmuştur.

\section{Verilerin toplanması}

Çalışmanın veri toplama araçları, Mehmet Akif Ersoy ve Muğla Sitkı Koçman Üniversitesinde 2016-2017 eğitim öğretim y1lı bahar döneminde Eğitim Fakültelerinde öğrenim gören beliren 
yetişkinlerden gönüllü öğrencilere, araştırmacılar tarafından ders saatlerinden sonra derslerini aksatmayacak şekilde uygulanmıştır. Uygulamalar yaklaşık 20 dakika sürmüştür.

\section{Verilerin analizi}

$\mathrm{Bu}$ araştırmada elde edilen verilerin analizinde, intihar olasılı̆̆ arasında ilişki olup olmadığını belirlemek için Pearson Momentler Çarpım Korelasyon Katsayısı, intihar olasılığ puanlarını stresle başetme becerileri ve öfke değişkenlerinin anlamlı bir şekilde yordayıp yordamadığını belirleyebilmek için Çoklu Regresyon Analizi (enter modeli) kullanılmıştır. Cinsiyet açısından intihar olasılığı puanlarında farklılık olup olmadığına ilişkin bağımsız gruplar $t$ testi kullanılmıştır. Analizlerden önce verilerin uygunluğunu sağlamak için uç değerlere bakılmış, 18 uç değer veri setinden atılmıştır. Daha sonra yapılan normallik analizinde verilerin normal dağıldığı saptanmıştır. Çoklu regresyon varsayımı sağlayabilmek için önce değişkenler arasındaki ilişkinin doğrusal olup olmadığı saçılma diyagramı ile incelenmiş ve ilişkinin doğrusal olduğu, kümeden sapan değerlerin olmadığ görülmüştür. Ayrıca regresyon varsayımını sağlayabilmek için modelde hata terimleri arasında ilişki olmaması gerekir. Bu doğrultuda öncelikle modelde otokorelasyonu test etmede kullanilan Durbin Watson değerine bakıldığında 1.5 ile 2.5 arasında olması arzulanan değerin (Kalayc1, 2006) 1.909 olduğu, modelde otokorelasyon olmadığı, b katsayılarının standart hatalarının çok küçük olduğu ve regresyon varsayımının sağlandığı görülmektedir. Veriler SPSS 20.0 paket programı kullanılarak çözümlenmiştir. İstatistiksel sonuçların yorumlanmasında .05 anlamlılık düzeyi dikkate alınmıştır.

\section{Bulgular}

Intihar olasılı̆̆l, stresle başetme becerileri ve öfke değişkenlerinin birbirleri ile ilişkilerine ve çoklu regresyon analizine ilişkin bulgular

İntihar olasılığı, stresle başetme becerileri ve öfke puanlarının birbirleri ile ilişkisi olup olmadığı pearson momentler çarpımı korelasyon katsayısı ile incelenmiş ve sonuçlar Tablo 1'de gösterilmiştir.

Tablo 1

İntihar Olasılığı, Stresle Başetme Becerileri (Problem Çözme, Sosyal Destek Arama, Kaçınma) ve Öfke (Öfke İçe, Öfke Dışa, Öfke Kontrol) Değişkenlerinin Pearson Momentler Çarpımı Korelasyon Katsayısı Sonuçları

\begin{tabular}{lccccccccc}
\hline $\begin{array}{l}\text { Değişken } \\
\text { ler }\end{array}$ & $\bar{X}$ & Ss & 1 & 2 & 3 & 4 & 5 & 6 & 7 \\
\hline 1-İO & 70.89 & 6.37 & - & $-.20^{* *}$ & -.03 & $.54^{* *}$ & $.45^{* *}$ & $.36^{* *}$ & $-.20^{* *}$ \\
2-PÇ & 27.76 & 3.89 & $-.20^{* *}$ & - & $.33^{* *}$ & $.27^{* *}$ & -.03 & -.11 & $.26^{* *}$ \\
3-SDA & 26.77 & 4.01 & -.03 & $.33^{* *}$ & - & -.06 & -.06 & -.07 & $.13^{*}$ \\
4-K & 21.73 & 4.07 & $.54^{* *}$ & $.27^{* *}$ & -.06 & - & $.33^{* *}$ & $.22^{* *}$ & -.06 \\
5-Ö̈ & 16.53 & 3.46 & $.45^{* *}$ & -.03 & -.06 & $.33^{* *}$ & - & $.36^{* *}$ & -.09 \\
6-ÖD & 13.75 & 2.94 & $.36^{* *}$ & -.11 & -.07 & $.22^{* *}$ & $.36^{* *}$ & - & $-.55^{* *}$ \\
7-ÖK & 24.99 & 4.19 & $-.20^{* *}$ & $.26^{* *}$ & $.13^{*}$ & -.06 & -.09 & $-.55^{* *}$ & - \\
\hline
\end{tabular}

$* \mathrm{p}<.05, * * \mathrm{p}<.01$

Not: İO=Intihar Olasılı $\breve{g}$, PÇ=Problem Çözme, SDA=Sosyal Destek Arama, K=Kaçınma, Öİ=Öfke İçe, ÖD=Öfke Dışa, ÖK=Öfke Kontrol

Tablo 1'de görüldüğü gibi, intihar olasıllğı puanları ile stresle başetme alt ölçeklerinden problem çözme ile negatif, kaçınma ile pozitif anlamlı bir ilişki bulunurken, stresle başetme alt ölçeği olan sosyal destek arama ile anlamlı ilişki bulunamamıştır. İntihar olasıllı̆̆ puanları ile öfke içe ve öfke dışa puanları arasında pozitif yönde anlamlı ilişki bulunurken, öfke kontrol puanları ile negatif yönde anlamlı ilişki bulunmuştur. Bu ilişkiler .70 ve üzeri olmadığından çoklu bağlantı sorunu olmadığı düşünülerek çoklu regresyon analizi yapılmıştır. 
İntihar olasılı̆g puanlarının stresle başetme ve öfke tarafından yordanıp yordanmadığının incelenmesi için çoklu regresyon analizi yapılmış ve sonuçlar Tablo 2'de gösterilmiştir.

Tablo 2

İntihar Olasılığı Puanlarının Stresle Başetme ve Öfke Tarafından Yordanıp Yordanmadığına İlișkin Coklu Regresyon (Enter) Analizi Sonuçları

\begin{tabular}{llllllllll}
\hline Değişkenler & $\mathrm{R}$ & $\mathrm{R}^{2}$ & $\mathrm{R}^{2}{ }_{\text {Değisim }}$ & $\mathrm{F}$ & $\mathrm{df}$ & $\mathrm{B}$ & $\beta$ & $\mathrm{t}$ & $\mathrm{p}$ \\
\hline Sabit & & & & & & 43.895 & & $10.006^{* *}$ & .000 \\
PÇ & & & & & & -.267 & -.163 & $2.795^{*}$ & .006 \\
SDA & .651 & .424 & .424 & $28.021^{* *}$ & $6 / 234$ & -.036 & -.023 & -.419 & .676 \\
K & & & & & & .564 & .360 & $6.307^{* *}$ & .000 \\
ÖI & & & & & & .506 & .275 & $4.827^{* *}$ & .000 \\
ÖD & & & & & & .307 & .142 & $2.161^{*}$ & .032 \\
ÖK & & & & & & -.171 & -.112 & -1.787 & .075 \\
\hline
\end{tabular}

$* \mathrm{p}<.05, * * \mathrm{p}<.001$

Not: $\mathrm{PÇ}=$ Problem Çözme, SDA=Sosyal Destek Arama, K=Kaçınma, Öİ=Öfke İçe, ÖD=Öfke Dişa, ÖK=Öfke Kontrol

Tablo 2'de görüldüğü gibi, stresle başetme ve öfke alt ölçekleri birlikte intihar olasılığını anlamlı düzeyde yordamaktadır $\left(R=.651, R 2=.424, F_{(6,234)}=28.021, \mathrm{p}<.001\right)$. Ad1 geçen değişkenler birlikte intihar olasılığının toplam varyansının \%42.4'ünü açıklamaktadır. Intihar olasılığını hangi değişkenlerin açıkladığına ilişkin sonuçlara bakıldığında, stresle başetme alt ölçeğinden olan problem çözme $(\beta=-.163, \mathrm{t}=2.795, \mathrm{p}<.05)$ 'nin negatif yönde, kaçınma $(\beta=.360, \mathrm{t}=6.307, \mathrm{p}<.001)$ alt ölçeğinin pozitif yönde, öfke ifade tarzının alt ölçeklerinden olan öfke içe $(\beta=.275, \mathrm{t}=4.827, \mathrm{p}<.001)$ ve öfke dişanın $(\beta=.142, \mathrm{t}=2.161, \mathrm{p}<.05)$ pozitif yönde intihar olasılığının önemli yordayıcıları olduğu bulunmuştur. Stresle başetme alt ölçeğinden olan sosyal destek arama ve öfke ifade tarzının alt ölçeklerinden olan öfke kontrolünün ise intihar olasılığının anlamlı birer yordayıcısı olmadığı görülmektedir.

\section{Farklılı̆̆a ilişkin bulgular}

İntihar olasılığı puanlarının cinsiyet açısından farklılaşıp farklılaşmadığını incelemek için bağımsız gruplar $t$ testi yapılmış ve sonuçlar Tablo 3'de gösterilmiştir.

Tablo 3

İntihar Olasılığı Puanlarının Cinsiyet Açısından Farklılaşıp Farklılaşmadığını İncelemek İçin Yapılan Bağımsız Gruplar t Testi Sonuçları

\begin{tabular}{llllllll}
\hline Bağımlı Değişken & Gruplar & $\mathrm{n}$ & $\bar{X}$ & $\mathrm{Ss}$ & $\mathrm{sd}$ & $\mathrm{t}$ & $\mathrm{p}$ \\
\hline İO & Kadın & 149 & 70.65 & 6.69 & 233 & .768 & .443 \\
& Erkek & 86 & 71.31 & 5.77 & & & \\
\hline
\end{tabular}

Not: İO=İntihar Olasilığ 1

Tablo 3'de görüldüğü gibi üniversite öğrencilerinin intihar olasıllı̆g puan ortalamas1 incelendiğinde en yüksek ortalamanın erkeklere ait $(\bar{X}=71.31)$ olduğu görülmektedir. Bağımsız gruplar $\mathrm{t}$ testi sonucuna bakıldığında ise cinsiyet açısından intihar olasılığı puanlarının farklılaşmadığı görülmektedir $\left(\mathrm{t}_{(233)}=.768, \mathrm{p}>.05\right)$.

\section{Tartıșma}

Araştırmada, beliren yetişkinlik döneminde olan üniversite öğrencilerinin intihar olasılığının stresle başetme ve öfke ile anlamlı ilişkiler gösterip göstermediği, intihar olasılığının, stresle başetme ve öfke tarafından yordanıp yordanmadığı ayrıca cinsiyet açısından intihar olasılığ puanlarının farklılaşıp farklılaşmadığı incelenmiştir. 
Araştırmanın ilk bulgusu intihar olasılığı ile stresle başetme alt ölçeklerinden problem çözmenin negatif, kaçınma ile pozitif yönde ilişkisi olduğu, stresle başetme alt ölçeği olan sosyal destek arama ile anlamlı ilişkisi olmadığıdır. İntihar olasılığ puanları ile öfke içe ve öfke dışa puanlarının pozitif yönde anlamlı ilişkisi olduğu, öfke kontrol puanları ile negatif yönde anlamlı ilişkisi olduğudur. Ayrıca stresle başetme alt ölçeklerinden problem çözme ve kaçınma ile öfke alt ölçeklerinden öfke içe ve öfke dışanın intihar olasılığını anlamlı olarak yordaması çalışmanın ilk bulgusu arasındadır. İntihar olasılı̆̆ının problem çözme ile negatif ilişki göstermesi beklenen bir durumdur. Regresyon analizi sonucunda da problem çözme intihar olasılığını ters yönde yordamaktadır. Bu sonuç problem çözmeyi sağlıklı olarak başarabilen bireylerin intihar olasılıklarının azalacağı anlamına gelmektedir. Kaçınma, öfke içe ve öfke dışa puanları ile intihar olasılığı pozitif yönde ilişkili bulunurken bu değişkenler de intihar olasılığını pozitif yönde yordamıştır. Bu bulgu bazı bireylerin öfke ile sağlıksız başetme mekanizması olarak kaçınma davranışları arttıkça, öfkelerini kendi içlerinde yaşamaları ya da zaman zaman kendilerine yöneltmeleri bazı bireylerin de öfkelerini daha çok dışarıya yöneltip öfkelerini arttırmalarından bu durumun da intihar olasılıklarını arttırmasından kaynaklanmış olabilir. Alan yazın incelendiğinde, Durak Batıgün (2004), yaptığı durum saptama çalışmasında öfke ve problem çözme davranışı ile intihar davranışlarının anlamlı olarak ilişkili olduğunu, ayrıca öfke, saldırganlık, yaşamı sürdürme nedenlerinin düşük olması ve dürtüselliğin intihar davranışlarının anlamlı yordayıcısı olduğunu belirtmiştir. Emir Öksüz ve Bilge (2014), üniversite öğrencilerinde intihar olasılığını inceledikleri çalışmalarında sosyal problem çözme ve kişilerarası öfkenin intihar olasılığını anlamlı olarak yordadığını saptamışlardır. Hisli Şahin, Onur ve Basım, (2008), çalışmaları sonucunda aynı anda hem yüksek düzeyde öfkeli ve dürtüsel olup, hem de problem çözme becerilerinde kendini yetersiz olarak algılayanların, intihar olasılığı açısından risk taşıdığını belirtmişlerdir. McAuliffe, Corcoran, Keeley ve Perry (2003) ve Dilli, Dallar ve Çakır (2010), intihar olasıllı̆ı ile düşük problem çözme becerisi arasında anlamlı bir ilişki saptamış, düşük problem çözme becerisine sahip olanların daha çok intihar eğiliminde olduğunu belirtmiştir. Ekici, Savaş ve Çıtak (2001), psikososyal stresörlerin intihar davranışı ile ilişkili olduğunu ortaya koymuştur. Ayrıca DSÖ (WHO, 2014) stresli durumlarla intiharın ilişkisini ortaya koyarken, Franklin ve diğerleri (2017), yaptıkları meta-analiz çalışmada stresli yaşam olayları ve öfkenin intiharda risk faktörü olduğunu belirtmişlerdir. Tüm bu çalışmalar araştırmanın bulgusunu destekler niteliktedir.

Çalışmada son olarak beliren yetişkinlerde intihar olasılığ 1 puanlarının cinsiyet açısından farklılaşmadığı sonucuna ulaşılmıştır. $\mathrm{Bu}$ sonuç öğrencilerin benzer kültürde yaşamalarından ve okul yıllarında birbirlerinden olumlu ya da olumsuz her şekilde etkileniyor olmalarından kaynaklanmış olabilir. Alan yazın incelendiğinde Kjoller ve Helweg Larsen (2000) İntihar düşüncelerinin genç bireylerde daha çok görüldüğünü, intihar düşüncelerinde kadın ve erkeklerde farklılık olmadığını saptamıştır. Emir Öksüz ve Bilge (2014), Gençtanırım (2004), Dilli, Dallar ve Çakır (2010), intihar olasılığının cinsiyete göre farklılaşmadığını ortaya koymuşlardır. $\mathrm{Bu}$ çalışmalar araştırma bulgusunu desteklemesine karşın farklılığa ilişkin oldukça fazla çalışma vardır. Bu çalışmalar incelendiğinde TÜIK (2016) verilerine göre erkeklerin intihar oranının kadınların intihar oranından daha fazla olduğu görülmüştür. Dünya Sağlık Örgütü (WHO, 2014) daha zengin ülkelerde erkeklerde görülen intihar oranının kadınlarda görülen intihar oranına göre üç kat daha fazla olduğu bildirilmiştir. Düşük ve orta gelirli ülkelerde ise bu oran yarıya düşmektedir. Yani intihar \%1.5 oranında erkeklerde daha fazla görülmektedir. Manchester Üniversitesi ve HQIP işbirliği ile yapılan çalışmada (2017) da erkeklerde görülen intihar oranının kadınlarda görülen intihar oranına göre daha yüksek olduğu ortaya konulmuştur. Hisli Şahin ve Durak Batıgün (2009) ve Mackenzie ve diğerleri, (2011) erkeklerin kadınlara göre daha çok intihar riski ve intihar düşüncesi taşıdığını belirlemişlerdir. Durak Batıgün (2005), kadınların daha fazla yaşamı sürdürme nedenine sahip olduklarını ve bu yüzden erkeklerden daha az intihar olasılığ bildirdiklerini belirtmektedir. Atkinson, Atkinson, Smith, Bem ve Nolen Hoeksena (2002) ve Kessler, Borges ve Walters (1999), kadınların intihar girişimi oranlarının yüksek olmasına karşın intihar girişiminin ölümle sonuçlanmasının erkeklerde daha yüksek olduğunu ortaya koymuşlardır. Nock ve diğerleri (2008), intiharın, 
erkekler arasında daha yaygın olduğunu belirtirken, ölümcül olmayan intihar davranıșlarının kadınlarda daha yaygın olduğunu saptamışlardır. Bu çalışmada kadın ve erkeklerin intihar olasılığı ifade etmelerinde bir farklılaşma bulunmamasına karşın alan yazındaki bu farklılık kadın ve erkeklerin farklı destek sistemleri kullanmalarından, kadınların ruhsal gerilimlerini sözel olarak daha kolay dışa vurmalarından kaynaklanıyor olabilir.

\section{Sonuç ve Öneriler}

Sonuç olarak bu araştırmada, beliren yetişkinlik döneminde olan üniversite öğrencilerinde intihar olasılığının stresle başetme ve öfke ile ilişkili olduğu, intihar olasıllı̆gıın stresle başetme alt ölçeklerinden problem çözme, kaçınma ve öfke alt ölçeklerinden öfke içe ve öfke dişa boyutları tarafından anlamlı olarak yordandığı bulgulanmıştır. Ayrıca stresle başetme alt boyutu olan sosyal destek arama ve öfke alt boyutu olan öfke kontrolü tarafindan anlamlı olarak yordanmadığı ve intihar olasılığ 1 puanlarının cinsiyet açısından anlamlı olarak farklılaşmadığ 1 saptanmıştır.

$\mathrm{Bu}$ araştırmanın sonuçlarına dayanarak bazı önerilerde bulunulabilir: Bu çalışmada küçük bir grup ile sınırlı sayıda risk faktörü ele alınarak çalışılmıştır. Yeni çalışmalarda daha büyük örneklem üzerinde ve çoklu risk faktörü ele alınarak çalışılabilir. Bu çalışmada intihar olasılığı koruyucu faktörleri ele alınmadığından yeni çalışmalarda koruyucu faktörler ve destek sistemleri ele alınarak kurgulama yapılabilir. Bu çalışmada her ne kadar cinsiyet açısından intihar olasılığında fark çıkmamış olsa da cinsiyeti ne olursa olsun beliren yetişkinlik dönemindeki bütün üniversite öğrencileri ile önleyici ve koruyucu çalışmalar planlanabilir. Çalışmada öfke, problem çözme becerileri ve kaçınma intihar olasılığında önemli bir değişken olarak bulunmuştur bu yüzden üniversiteler bünyesindeki PDR merkezlerinde beliren yetişkinlik döneminde bulunan üniversite öğrencilerinin öfkeleri ile başetme becerileri, etkili problem çözmeleri ve kendilerini daha iyi tanıyarak, daha rahat ifade edebilmelerine yönelik çalışmalar planlanabilir.

Her çalışmada olduğu gibi bu çalışmanın da bir takım sınırlılıkları mevcuttur. $\mathrm{Bu}$ çalışmada batı illerinde iki üniversitede bulunan belirgin yetişkinler ele alınmıştır. Üniversite öğrencisi olmayan belirgin yetişkinler ulaşılma zorluğu olduğu düşünülerek çalışmaya dahil edilememiştir. Ayrıca çalışmada sadece batı illerinde bulunan iki üniversiteden gönüllü beliren yetişkinler arasından seçilen bir çalışma grubu oluşturulmuştur bu da çalışmanın diğer bir sınırlılığını oluşturmaktadır. Bir diğer sınırlılık ise çalışmaya dahil edilen beliren yetişkinlerin tamamen sağlıklı gruptan oluşmasıdır. Daha önce intihar teşebbüsü olanlar ve klinik tedavi sürecinden geçmiş olanlar karıştırıcı etken olmasınlar diye çalışmaya dahil edilmemiştir.

\section{Kaynaklar}

American Association of Suicidology (2014). Depression and suicide risk. Erişim adresi: https://www.suicidology.org/portals/14/docs/resources/factsheets/2011/depressionsuicid e2014.pdf

Apaydın, H., Özdemir, Ş. ve Zaroğlu Ünal, A. (2016). İntihar girişiminde bulunan bireylerde bazı değişkenlerle intihar girişimi ilişkisi. Amasya Üniversitesi İlahiyat Fakültesi Dergisi, 6, 7-44.

Arsel, C. O. ve Durak Batıün, A. (2011). İntihar ve cinsiyet: Cinsiyet rolleri, iletişim becerleri, sosyal destek ve umutsuzluk açısından bir değerlendirme. Türk Psikoloji Dergisi, 26 (68), 1-10.

Arnett, J. J. (2000). Emerging adulthood: A theory of development from the late teens through the twenties. American Psychologist, 55, 469-480.

Aslan, B. ve Durak Batıün, A. (2017). Ebeveyn kabul/reddi ile intihar olasılığı arasındaki ilişkide yaşam amaçlarının aracı rolü. Türk Psikoloji Dergisi, 32(79), 67-76.

Atak, H. ve Çok, F. (2010). İnsan yaşamında yeni bir dönem: Beliren yetişkinlik. Çocuk ve Gençlik Ruh Sağlı̆̆ Dergisi, 17(1), 39-50.

Atkinson R. L., Atkinson, R. C., Smith, E. E., Bem, D. J. ve Nolen Hoeksena, S. (2002). Psikolojiye giriş. Y. Alagon (Çev.). 2. Baskı, Ankara: Arkadaş Yayınları. 
Atlı, Z. (2007). İntihar olasıllı̆ı ölçeği (IOÖ) 'nin klinik örneklemdeki geçerlik ve güvenirlik Çalışması (Yayımlanmamış yüksek lisans tezi). Adnan Menderes Üniversitesi Sağlık Bilimleri Enstitüsü, Aydın.

Atlı, Z., Eskin, M. ve Dereboy, Ç. (2009). İntihar olasıllı̆̆ ölçeğinin (İÖ) klinik örneklemde geçerlik ve güvenirliği. Klinik Psikiyatri, 12, 111-124.

Aysan, F. (2003). Başaçıkma stratejisi ölçeğinin Türkçe formunun oluşturulması Ege Eğitim Dergisi 3(1), 123-132.

Buzlu, S. (1999). Gençlerde madde kullanımı, intihar, stresle başa çıkma yolları. Hemşirelik Bülteni, 12(145), 1-11.

Dilli, D., Dallar, Y. ve Çakır, İ. (2010). Psychological characteristics of adolescent suicide attempters presenting to a pediatric emergency service. Turk J Med Sci, 40(3), 377-390.

Doğan, A. ve Cebioğlu, S. (2011). Beliren yetişkinlik: Ergenlikten yetişkinliğe uzanan bir dönem. Türk Psikoloji Yazıları, 14(28), 11-21.

Durak Batıgün, A. (2004). İntihar ile ilişkili bazı değişkenler: Öfke/saldırganlık dürtüsel davranışlar, problem çözme becerileri, yaşamı sürdürme nedenleri. Kriz Dergisi, 12(2), 49-61.

Durak Batıgün, A. (2005). İntihar olasılığı: Yaşamı sürdürme nedenleri, umutsuzluk ve yalnızlık açısından bir inceleme. Türk Psikiyatri Dergisi, 16(1), 29-39.

Durak Batıgün, A. (2008). İntihar olasılığı ve cinsiyet: İletişim becerileri, yaşamı sürdürme nedenleri, yalnızlık ve umutsuzluk açısından bir inceleme. Türk Psikoloji Dergisi, 23(62), 65-75.

Eisenberg, D., Gollust, S. E., Golberstein, B. A. E. ve Hefner, J. L. (2007). Prevalence and correlates of depression, anxiety, and suicidality among university students. American Journal of Orthopsychiatry, 77(4), 534-542.

Ekici, G., Savaş, H. A. ve Çıtak, S. (2001). İntihar riskini artıran psikososyal etmenler. (Sosyal güvence yokluğu, göç ve diğer stresörler). Anadolu Psikiyatri Dergisi, 2(4), 204-212.

Emir Öksüz, E. ve Bilge, F. (2014). Üniversite öğrencilerinin intihar olasıl1klarının incelenmesi. Eğitim ve Bilim, 39(171), 407-420.

Franklin, J. C., Ribeiro, J. D., Bentley, K. H., Huang, X. H., Musacchio, K. M., Chang, B. P., Fox, K. R., Kleiman, E. M., Jaroszewski, A. C. ve Nock, M. K. (2017). Risk factors for suicidal thoughts and behaviors: A meta-analysis of 50 years of research. Psychological Bulletin, 143(2), 187-232.

Gençtanırım, D. (2004). Ergenlerde intihar olasılı̆̆ının yordanması (Yayımlanmamış yüksek lisans tezi). Hacettepe Üniversitesi Sosyal Bilimler Enstitüsü, Ankara.

Gonong W. F. (2002). Tıbbi fizyoloji. Türk Fizyolojik Bilimler Derneği (Çev.). Ankara: Nobel Tip Kitabevleri.

Görgülü, T. ve Tutarel Kışlak, Ş. (2014). Erkek hükümlü ve tutukluların boyun eğici davranışları, depresyon ve intihar olasılıkları. Nöropsikiyatri Arşivi, 51, 40-45.

Hankins, G. ve Hankins, C. (1988). Prescription for anger: Coping with angry feelings and angry people. New York: Warner.

Hisli Şahin, N. ve Durak Batıgün, A. (2009). Lise ve üniversite öğrencilerinde intihar riskini belirlemeye yönelik bir modelin sinanması. Türk Psikiyatri Dergisi, 20(1), 28-36.

Hisli Şahin, N., Onur, A. ve Basım, H. N. (2008). İntihar olasılığının, öfke, dürtüsellik ve problem çözme becerilerindeki yetersizlik ile yordanması. Türk Psikoloji Dergisi, 23(62), 79-88.

Kalayc1, Ş. (2006). SPSS uygulamalı çok değişkenli istatistik teknikleri. Ankara: Asil Yayıncılık.

Karbeyaz, K., Toygar, M. ve Çelikel, A. (2016). Completed suicide among university student in Eskisehir, Turkey. Journal of Forensic and Legal Medicine, 44, 111-115.

Kessler, R. C., Borges, G. ve Walters, E. E. (1999). Prevalence of and risk factors for lifetime suicide attempts in the National Comorbidity Survey. Arch. Gen. Psychiatry, 56(7), 617-26.

Kjoller, M. ve Helweg Larsen, M. (2000). Suicidal ideation and suicide attempts among adult Danes. Scand J Public Health, 28(1), 54-61. 
Klonsky, E. D., May, A. M. ve Saffer, B. Y. (2016). Suicide, suicide attempts, and suicidal ideation. Rev. Clin. Psychol., 12, 307-330.

Korb, I. ve Plattner, I. E. (2014). Suicide ideation and depression in university students in Botswana. Journal of Psychology in Africa, 24(5), 420-426.

Mackenzie, S., Wiegel, J. R., Mundt, M., Brown, D., Saewyc, E., Heiligenstein, E., Harahan, B. ve Fleming, M. (2011). Depression and suicide ideation among students accessing campus healthcare. Am J Orthopsychiatry, 81(1), 101-107.

Manchester University \& HQIP (2017). Suicide by children and young people. National Confidential Inquiry into Suicide and Homicide by People with Mental Illness. Erişim adresi: http://research.bmh.manchester.ac.uk/cmhs/research/centreforsuicideprevention /nci/reports/cyp_2017_report.pdf

McAuliffe, C., Corcoran, P., Keeley, H. S. ve Perry, I. J. (2003). Risk of suicide ideation associated with problem-solving ability and attitudes toward suicidal behavior in university students. Crisis, 24(4), 160-167.

Nock, M. K., Borges, G., Bromet, E. J. Cha, C. B., Kessler, R. C. ve Lee, S. (2008). Suicide and suicidal behavior. Epidemiologic Reviews, 30, 133-154.

Özer, K. (1994). Sürekli öfke (SL-öfke) ve öfke ifade tarzı (öfke-tarz) ölçeklerinin ön çalışması. Türk Psikoloji Dergisi, 9(31), 26-35.

Şener, S. (1994). Çocuklarda ve ergenlerde depresyon. Depresyon Monografları Serisi, 7, 313.

Takahashi, Y. (2001). Depression and suicide. JMAJ, 44(8), 359-363.

TÜIKK (2016). İntihar istatistikleri 2015. Erişim adresi: http://www.tuik.gov.tr /PreHaberBultenleri.do?id= 21516

Westefeld, J. S., Whitchard, K. A. ve Range, L. M. (1990). College and university students suicide. The Counseling Psychologist, 18(3), 464-476.

WHO (2014). Preventing suicide a global imperative. Luxembourg: WHO Library Catalog

Vander A. J., Sherman J. H. ve Luciano D. S. (2001). Human Physiology (8th Ed). USA: McGraw Hill.

\section{Extended Abstract}

\section{Introduction}

Suicide is an extremely serious problem observed among both young people and adults in the world and Turkey. A suicide attempt is expected to leave permanent traces in the form of either physical or psychological problems. The suicide prevention report issued by the World Health Organization (2014) pointed out that suicide is a preventable incidence, but in every forty seconds a person dies of suicide in anywhere in the world and that suicide is the second most common cause of death among young people aged 15-29 and is a common health problem.

Investigation of the suicide possibility among emerging adults as a population with great propensity to suicide is of utmost importance. Moreover, as the current study will also address stress coping and anger as well as possibility of suicide, it is believed to contribute to elicitation of the extent to which stressful living conditions of young people in the adulthood period affect the likelihood of committing suicide. When how much stress and anger is influential on the likelihood of committing suicide has been determined in the current study, it is expected to be a pioneering study for the preventive studies focusing on the effect of these two variables together on the likelihood of committing suicide. Furthermore, by determining the prevalence of the likelihood of committing suicide among male and female young people who are in their adulthood period, the current study can make the planning of preventive works for these people possible and can make contributions to the existing knowledge in the literature on the likelihood of committing suicide. In this connection, the purpose of the study was set to be to determine whether the likelihood of committing suicide among emerging adults is correlated with stress-coping and anger and the extent to which the likelihood of committing suicide is predicted by stress-coping skills and anger. 


\section{Method}

The study was conducted on the basis of the relational survey model. The universe of the study is comprised of the education faculty students of Mehmet Akif Ersoy and Muğla Sitkı Koçman Universities. The study group of the current research consists of a total of 235 university students attending these education faculties in 2016-2017 academic years. The students participated in the study on a volunteer basis and 149 (63.4\%) of them are females and 86 (36.6\%) are males; 69 are from the science department, 108 are from the Turkish and mathematics departments and 58 are from social sciences departments; 107 are first-year students, 32 are second-year students, 64 are third-year students and 32 are fourth-year students; their mean age is 20.80. In order to determine the likelihood of committing suicide in the current study, the Suicide Likelihood Scale developed by Cull and Gill and adapted to Turkish by Atli, Eskin and Dereboy (2009) was used; in order to evaluate their ways of stress-coping, the Stress Coping Strategies Scale developed by Amirkhan and adapted to Turkish by Aysan (2003) was used and in order to determine the state of anger, the Anger Expression Style Scale developed by Spielberger and adapted to Turkish by Özer (1994) was used. In the analysis of the collected data, Pearson Product Moment Correlation Coefficient, Multiple Regression Analysis and independent samples t-test were employed. Prior to these analyses, outliers were examined to ensure the suitability of the data set and 18 outliers were excluded from the data set. Then, the normality analysis was run and the data were determined to be normally distributed. The analyses conducted to test whether the multiple regression analysis assumption is satisfied revealed that this assumption was satisfied. The data were analyzed by using SPSS 20.0 program package. In the interpretation of the statistical results, the significance level was accepted to be .05 .

\section{Results}

As a result, in the current study it was found that in the university students in the emerging adulthood period, the likelihood of committing suicide is correlated with stress coping and anger and that the likelihood of committing suicide is significantly predicted by the sub-dimensions of problem solving and avoidance in the stress coping scale and by the sub-dimensions of anger in and anger out in the anger scale. Moreover, it was determined that the likelihood of committing suicide is not significantly predicted by the sub-dimension of seeking for social support in the stress coping scale and by the sub-dimension of anger control in the anger scale and that the likelihood of committing suicide scores do not vary significantly by gender.

\section{Discussion}

The first finding of the study is that the sub-dimension of problem solving is negatively and the sub-dimension of avoidance is positively and significantly correlated with the likelihood of committing stress; yet, that the sub-dimension of seeking for social support is not significantly correlated with it. The likelihood of committing suicide scores are in a positive and significant correlation with the anger in and anger out scores and in a negative and significant correlation with the anger control scores. It was also found that the sub-dimensions of problem solving and avoidance in the stress coping scale and the sub-dimensions of anger in and anger out in the anger scale significantly predict the likelihood of committing suicide. It was an expected outcome that the likelihood of committing suicide is negatively correlated with problem solving. The regression analysis also revealed that problem solving inversely predict the likelihood of committing suicide. This indicates that the likelihood of committing suicide of individuals who can solve their problems in a healthy manner will decrease. The likelihood of committing suicide was found to be in a positive correlation with avoidance, anger in and anger out scores and these variables were found to positively predict the likelihood of committing suicide. This may indicate that with increasing anger and tendency towards avoidance as an unhealthy means of solving problems, individuals experience their anger inside and from time to time direct it to themselves or they may direct it outside and they increase it and as a result, their likelihood of committing suicide may increase. In the literature, findings reported by Durak Batıgün (2004), 
Emir Öksüz and Bilge (2014), Hisli Şahin, Onur and Basım, (2008), McAuliffe, Corcoran, Keeley and Perry (2003), Dilli, Dallar and Çakır (2010), Ekici, Savaş and Çıtak, (2001), DSÖ (WHO, 2014), Franklin et al. (2017) support these findings of the current study.

The final finding of the current study is that the suicide likelihood scores do not vary significantly by gender. This might be because the students live in similar cultures and during their school years they are positively or negatively affected by each other. In the literature, Kjoller and Helweg Larsen, (2000) Emir Öksüz and Bilge (2014), Gençtanırım (2004), Dilli, Dallar and Çakır (2010) also showed that suicide likelihood does not vary significantly depending on gender. Though these studies support the finding of the current study, there are many studies showing that it varies significantly (Atkinson, Atkinson, Smith, Bem \& Nolen Hoeksena, 2002; Durak Batıgün, 2005; Hisli Şahin \& Durak Batıgün, 2009; Kessler, Borges \& Walters, 1999; Mackenzie et al. 2011; Manchester University \& HQIP, 2017; TÜİK, 2016, WHO, 2014). These studies have revealed that though the rate of attempts to commit suicide is higher among women, the rate of these attempts' ending up with death is higher among men; thus, the rate of deaths caused by suicide is higher for man. 